\title{
Clinical evaluation and induced corneal vascularization study by native and anionic collagen membranes in rabbits corneas
}

\author{
Avaliação clínica e estudo da vascularização corneal induzida pelas \\ membranas de colágeno nativo e aniônico em córneas de coelhos
}

\author{
Thaís Eliane Binotto ${ }^{1}$ \\ Alexandre Lima de Andrade ${ }^{2}$ \\ Thiago André Carreo Costa ${ }^{3}$ \\ Ana Maria Guzzi Plepis ${ }^{4}$ \\ Rodrigo Antonio Lopes $^{5}$ \\ Wilson Machado Souza ${ }^{6}$
}

\begin{tabular}{|c|}
\hline ABSTRACT \\
\hline $\begin{array}{l}\text { Purpose: To evaluate the corneal vascularization (CV) and the clinical } \\
\text { aspects induced by interlamellar graft with native (NCM) and anionic } \\
\text { (ACM) collagen membranes in rabbits corneas. Methods: An interla- } \\
\text { mellar graft with a } 0.25 \mathrm{x} 0.25 \mathrm{~cm} \text { NCM (group } 1) \text { or ACM (group } 2 \text { ) } \\
\text { fragment was performed in the right eye (treated eye). In the left eye, } \\
\text { an estromal tunnel was done (control eye). Sixteen rabbits were used, } \\
\text { and they were subdivided into two experimental groups of eight animals } \\
\text { each. The clinical evaluation was performed at the } 1^{\text {st }}, 3^{\text {rd }}, 7^{\text {th }}, 15^{\text {th }} \text { and } 30^{\text {th }} \\
\text { postoperative days. Corneal vascularization analysis was performed } \\
\text { after } 30 \text { days by the Images Analizator System Leica Qwin-550 }{ }^{\circledR} \text { Re- } \\
\text { sults: After } 7 \text { days, corneal vascularization was observed at about } \\
2.25 \pm 0.71 \text { mm (NCM) and at about } 1.0 \pm 1.69 \text { mm (ACM), respectively, } \\
\text { from the limbus in direction to the central cornea. After } 15 \text { days, CV } \\
\text { increased in both groups (5.25 } \pm 1.03 \text { mm - NCM; } 2.0 \pm 2.39 \text { mm - ACM) } \\
\text { and then progressively decreased until day } 30 \text { ( } 2.25 \pm 2.10 \text { mm - NCM; } \\
0.75 \pm 2.12 \text { mm - ACM). The statistical analysis indicated that the } \\
\text { averages of the distances from the limb vessels to the grafts observed } \\
\text { after } 7 \text { and } 15 \text { days had not differed statistically ( } p=0.17) \text {, and after } 15 \\
\text { and } 30 \text { postoperative days had tendency to differ statistically ( } p=0.09 \text { ). } \\
\text { The control eyes did not present any changes. Conclusion: The inter- } \\
\text { lamellar graft with native and anionic collagen membranes induced } \\
\text { corneal vascularization when applied to rabbit corneas, but anionic } \\
\text { collagen membrane induced a smaller corneal vascularization when } \\
\text { compared to native collagen membrane. Although further studies are } \\
\text { required, the results found in this study demonstrated the usefulness } \\
\text { of interlamellar graft with native and anionic collagen membranes in } \\
\text { keratoplasties. These membranes consists in one more graft option for } \\
\text { the surgical treatment of corneal repair in rabbits and others animals, } \\
\text { when other forms of medical and surgical treatment are not effective. }\end{array}$ \\
\hline
\end{tabular}

Keywords: Membranes, artificial; Cornea; Collagen; Anions; Disease models, animal; Rabbits

\section{INTRODUCTION}

The cornea is a unique portion of the outer fibrous tunic of the eye. It is transparent and serves a major refractive function while maintaining a tough, physical, and impermeable barrier between the eye and the environment. However, it is the most vulnerable portion of the fibrous tunic of 
the eye. Fortunately, most are amenable to medical and surgical therapy. The most important goals of the corneal treatment are to preserve or improve the quantity and quality of light entering the eye in the presence of corneal opacities ${ }^{(1)}$. Autogenous or xenologous grafts (biological membranes) are necessary in the corneal repair with significant tissue loss. Nevertheless, it use induces corneal vascularization and the occurrence of late corneal pigmentation, fibrosis and cicatricial leu$\mathrm{koma}^{(2)}$ that would result in a partial success of corneal regeneration, consisting only in a tectonic keratoplasty ${ }^{(3)}$.

Despite the numerous surgical techniques that have been described, there are few reports on corneal vascularization, although corneal repair using different tissues has been well studied $^{(2,4-6)}$. Nowadays, the state-of-art ophthalmology has supplied ways for the treatment of many corneal diseases employing the artificial membranes produced in laboratory. Then, those researches generate a great interest on finding an ideal material for corneal restoration, as example, the use of shields and collagen contact lenses ${ }^{(7)}$. Some have studied the application of chitosan membrane (CM) in interlamellar graft in rabbits cornea, and concluded that $\mathrm{CM}$ is able to induce corneal vascularization, but its use is possible in keratoplasty ${ }^{(8)}$. The choice for collagen membrane was due to the excellent biocompatibility of this material, and due to its biological characteristics such as biodegradability and low antigenicity ${ }^{(9)}$. Therefore, the purpose of this study was to evaluate the clinical aspects and the corneal vascularization $(\mathrm{CV})$ induced by native and anionic collagen membranes in rabbit corneas.

\section{METHODS}

\section{Animals and experimental groups}

Experiments were carried out in accordance with ARVO guidelines for the care and use of laboratory animals; and all animal protocols were approved by the Investigational Review Board of Animal Experiments - Paulista State University.

Sixteen New Zealand albino rabbits of both genders, with an average weight of $3.0 \mathrm{~kg}$, were used. They were submitted to an ophthalmic exam for the exclusion of ocular diseases. Two experimental groups were composed (G1 and G2). The animals of $\mathrm{G} 1$ received a fragment of native collagen membrane (NCM) and the animals of $\mathrm{G} 2$ received a fragment of anionic collagen membrane (ACM).

\section{Biological membrane}

The NCM and ACM were manufacture and supplied by Biochemical and Biomaterial Laboratory of the Chemical Institute of São Paulo University - USP - São Carlos, Brazil ${ }^{(10-11)}$.

\section{Surgical procedure}

The animals were anaesthetized by dissociate anesthesia with ketamine $(35 \mathrm{mg} / \mathrm{kg})$ and xylazine $(5 \mathrm{mg} / \mathrm{kg})$ applied by intramuscular injection. Then, a stromal interlamellar tunnel was performed with slit knife (Alcon ${ }^{\circledR}$ ) in the middle portion of the corneal stroma from the limb toward the central vision. On the G1 animals (right eye), after corneal stroma tunnel performance, a NCM fragment of $0.5 \times 0.5 \mathrm{~cm}$ was implanted in the bag until the visual axis. The G2 animals received a ACM fragment of the same dimensions as the implanted in the animals of group 1. The left eye of each animal was used as a control eye. In which only a corneal stroma tunnel was performed. The figure 1 shows a schematic representation of the surgical procedure.

As a postoperative procedure, the animals received topical ciprofloxacin hydrochloride three times a day (TID) and buprenorphine $(0.05 \mathrm{mg} / \mathrm{kg}) \mathrm{BID}$, both for seven days to prevent bacterial infection and to promote postoperative analgesia, respectively.

\section{Clinical evaluation}

The clinical evaluations were performed at the $1^{\text {st }}, 3^{\text {rd }}, 7^{\text {th }}$, $15^{\text {th }}$ and $30^{\text {th }}$ postoperative days. The ocular signs evaluated were: photophobia/blepharospasm, conjunctival hyperemia, ocular discharge, corneal transparency and pigmentation using a scale of: (-), abscense of signs; (+), mild; (++), moderate; and $(+++)$, intense ${ }^{(2)}$.

The fluorescein staining test was performed to verify the presence of epithelial defects. The animals were evaluated by two blind examiners.

\section{Corneal vascularization study}

After the $7^{\text {th }}, 15^{\text {th }}$ and $30^{\text {th }}$ postoperative days, all the animals were submitted the cornea morphological exam for evaluation and measurement of angiogenesis induced by membranes. Then, the Analyzer Image System Leica Qwin $550^{\circledR}$ was used to register the distance of corneal vessels from the limb, as well as, the corneal vascularized area in relation to the corneal total area. The camera system was maintained in the same distance from the corneal surface and the images were captured for analysis.

\section{Statistical analysis}

The data were statistically analyzed through variance analysis (ANOVA) by Software Graphpad Instat ${ }^{\oplus}$ v.2.01. The data was considered significant when $\mathrm{P}<0.05$.

\section{RESULTS}

\section{Clinical evaluation}

All the corneas were negative to fluorescein-dye uptake 30 days after the surgery. The ophthalmic signs varied between animals and groups. In both groups (NCM and ACM) no ocular discharge was observed. The photophobia/blepharospasm and conjunctival hyperemia showed to be harder in the animals of $\mathrm{G} 2$ in the first days, but decreased over time and was absent at the $30^{\text {th }}$ postoperative day. Those ocular signs were not observed in G1 animals. Corneal opacity was not present in none of the animals studied. The corneal edema was 


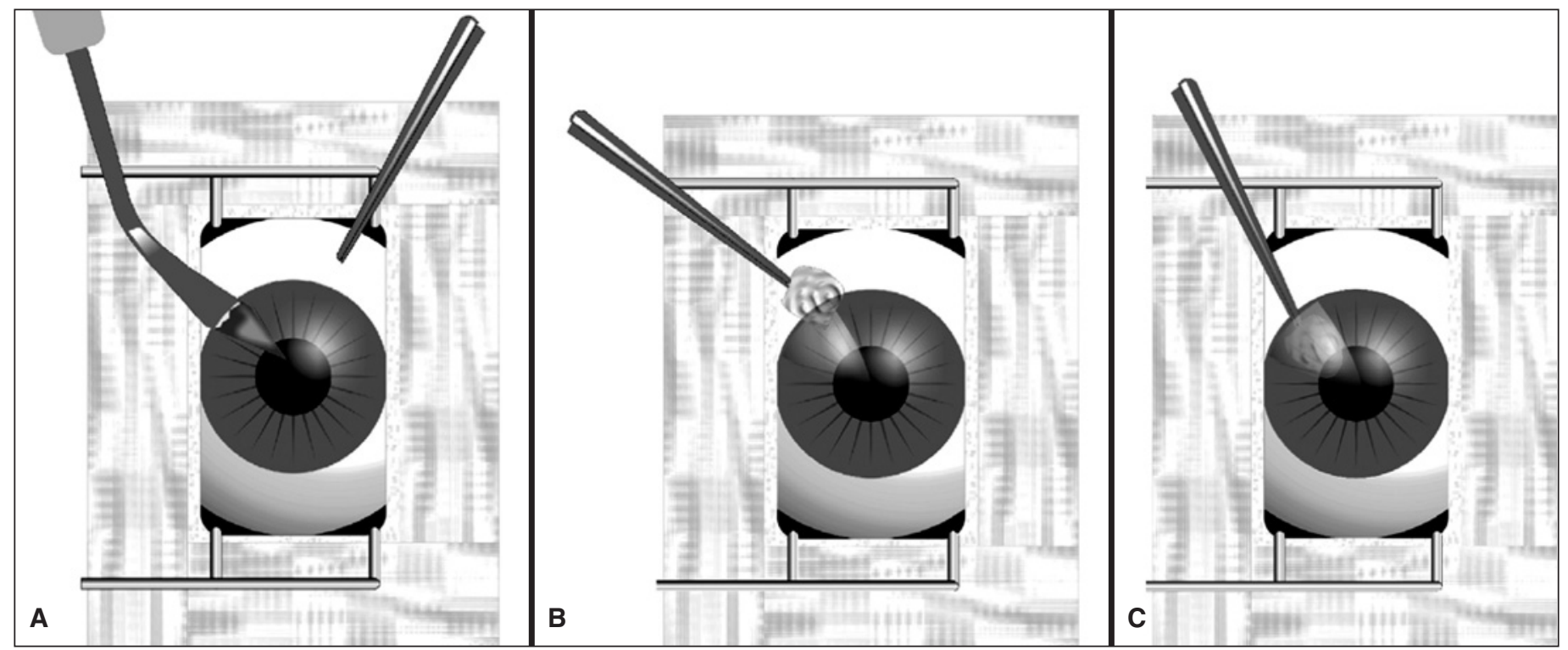

Figure 1 - Schematic representation of the surgical procedure of collagen membrane graft. A) Manufacture of the corneal stroma tunnel using the slit knife; B) Interlamellar graft of collagen membrane; C) Grafted collagen membrane in the corneal stroma .

restricted to the graft area until the $15^{\text {th }}$ postoperative day and absent at the $30^{\text {th }}$ postoperative day on the eyes of $\mathrm{G} 1$ animals. However, on the eyes of $\mathrm{G} 2$ animals, it was mild and restricted to the graft area. The pupillary diameter varied between 0.4 and $0.7 \mathrm{~cm}$ and was similar to the measured before surgery in both groups.

The corneal vascularization developed after the $7^{\text {th }}$ postoperative day in both groups, but it was marked on the G1 animals. Corneal vascularization was not observed in the fellow cornea (control eye) in both groups.

The grafts were integrated into the rabbit cornea without clinical rejection signs in none of the animals. The figure 2 illustrates the postoperative evolution of NCM and ACM grafts 30 days after surgery.

\section{Corneal vascularization study}

A few rectilinear vessels from the limbus were noted on the animals of both groups in the $7^{\text {th }}$ postoperative day. In $\mathrm{G} 1$, (NCM) CV was observed at $2.25 \pm 0.71 \mathrm{~mm}$ from the limbus. The distance of the corneal vessels from the limbus were $5.25 \pm 1.03 \mathrm{~mm}$ and $2.25 \pm 2.10 \mathrm{~mm}$ on the $15^{\text {th }}$ and $30^{\text {th }}$ postoperative days, respectively. The statistical analysis indicated that the averages distances of corneal vessels from the limbus toward the grafts differed statistically $(p<0.05)$, after 7 and 15, and after 15 and 30 days after surgery. The corneal total area values in the left eyes (control) after 30 days averaged about $1.56 \pm 0.14 \mathrm{~cm}^{2}$.

In G2 (ACM), 7 days after surgery, a few corneal vessels were observed in fifty per cent of the animals and it distanced in average about $1.0 \pm 1.69 \mathrm{~mm}$ from the limbus. Fifteen days and 30 days after the surgery, the corneal vessels distanced about $2.0 \pm 2.39 \mathrm{~mm}$ and $0.75 \pm 2.12 \mathrm{~mm}$ from the limbus, respectively. The statistical analysis indicated that the ave- rages of the distances from the limbus vessels toward the grafts did not differ statistically ( $p=0.17)$ after 7 and 15 days. However, after 15 and 30 days they showed a tendency to differ statistically $(p=0.09)$. The value of the total corneal area in this group was about $1.51 \pm 0.11 \mathrm{~cm}^{2}$ in the $30^{\text {th }}$ postoperative day. The value of the total corneal area from the right eyes (NCMG1) after 30 days of surgery was, in average, $1.59 \pm 0.17 \mathrm{~cm}^{2}$. The value of the corneal vascularization area was, in average, of $0.05 \pm 0.05 \mathrm{~cm}^{2}$. The ratio between corneal vascularization area and total corneal area was in average $0.34 \pm 0.30 \%$. The analysis of the total corneal area and corneal vascularization area on the animals of Group $2(\mathrm{ACM})$ were in average $1.55 \pm$ $0.08 \mathrm{~cm}^{2}$ and $0.01 \pm 0.02 \mathrm{~cm}^{2}$, respectively. The ratio between the total cornea area and vascularization cornea was in average $0.04 \pm 0.11 \%$. There was no statistical difference between the groups in all periods of evaluations; however, there was a statistical difference between both groups in comparison to control eyes that did not show corneal vascularization.

\section{DISCUSSION}

Many methods have been developed to study angiogenesis because, when known how to control it, there is a great probability to prevent many of the major causes of visual $\operatorname{loss}^{(12-13)}$. The technique of corneal vascularization induction was developed by Gimbrone Junior et al. (1974) ${ }^{(14)}$.

We opted to study the angiogenic capacity of NCM and ACM membrane in rabbit corneas because it is an original biomaterial, with excellent biocompatibility and weak antigenicity ${ }^{(9)}$. Several methods were described for the repair of corneal ulcers and perforations with autogenous and xenologous grafts ${ }^{(2-6,8,15-16)}$. Corneal opacification may be the final 


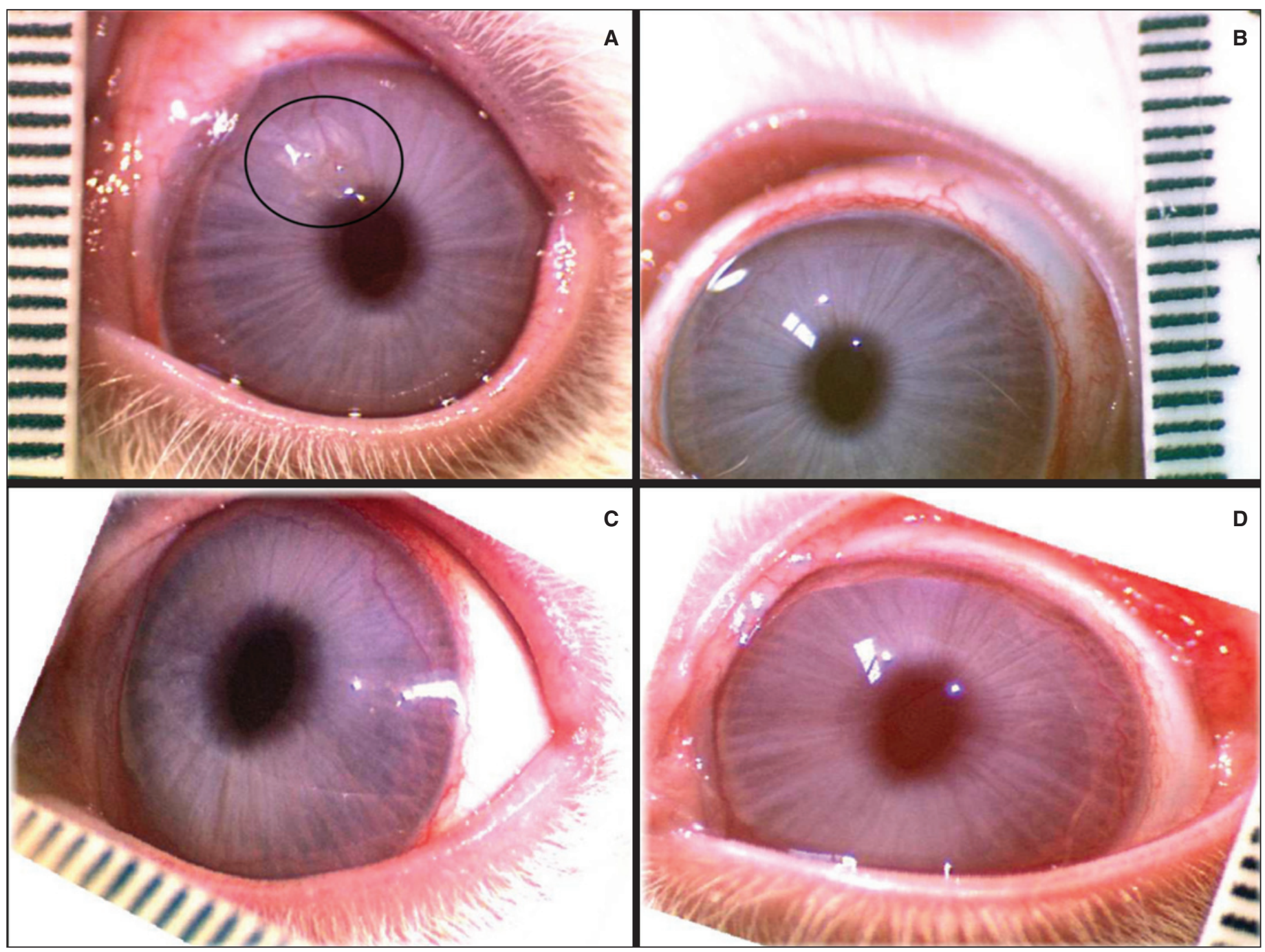

Figure 2 - The late clinical postoperative period of ACM and NCM grafts and normal cornea at the $30^{\text {th }}$ postoperative day. A) Note the presence of NCM graft (demarcated area) and corneal vessels; B) Normal cornea as control of A; C) Note the discrete presence of ACM (demarcated area) and absence of corneal vascularization; D) Normal cornea as control of C.

results ${ }^{(2,15-16)}$. The cornea is a great experimental model for studing angiogenesis, because of its transparency and absence of vascular tissue, which allows to measure the vascular growth from limbus ${ }^{(12-13)}$.

The photophobia and blepharospasm were marked in the earlier periods ( 3 days) in both groups. It could be due to the corneal edema, stimulating the corneal epithelium nerves ${ }^{(2,17)}$. Probably all clinical signs noted herein could be more intense if buprenorphine was not performed. In this case, it promoted a better postoperative analgesia and ocular comfort. We can also state that it was used for bioethical aspects.

The corneal opacity occurs due to stromal collagen fibrils dissociation $^{(17-18)}$ and epithelial and/or endothelial disfunction. In all studied animals, this opacity was not observed near the grafts, as well as the scarring leukoma in graft area and near it. In fact, the scarring leukoma can be noted using others biological membranes ${ }^{(2,4,8,15-16)}$. In this study, it was only pos- sible to observe the stromal tunnel and the graft until the $15^{\text {th }}$ postoperative day in both groups. In G1 (NCM), the graft could be barely noted at the $30^{\text {th }}$ postoperative day and no corneal vessels were seen. In G2 (ACM) the graft and a discrete corneal vascularization were observed in the end of the analysis.

This corneal vascularization was observed on the $7^{\text {th }}$ postoperative day and it was characterized by few rectilinear vessels in both groups. The corneal vessels reduced after 15 days trending to disappear in a posterior time. These findings corroborate $^{(19)}$ with the described phenomenon that occurs due to liberation of angiogenic factors. Some authors ${ }^{(20)}$ demonstrated the participation of interleucine-8 (Il-8) delivered by the corneal matrix and its angiogenic effect on corneal vascularization, occurring toward the corneal injury. The genesis and involution of corneal vascularization have not the same significance, comparatively with that observed ${ }^{(16)}$. 
The authors concluded that a major intensity of the phenomenon occurs when the preserved amniotic membranes are used in keratectomies repair. All of them studied this phenomenon for a long postoperative period, what we were not able to do in this study.

The Analytical System of Images Leica Qwin $550^{\circledR}$ used for the evaluation of corneal vascularization was efficient, therefore allowing us to calculate the corneal vascularization area. Despite the fact that corneal vascularization area did not present a significant difference between the studied groups, half of animals submitted to NCM implant $(n=4)$ showed persistent vascularization at the $30^{\text {th }}$ postoperative day. Adicionally, just one animal with ACM implant $(n=1)$ showed vessels at the $30^{\text {th }}$ postoperative day. This phenomenon can be explained by some contamination in the surgical procedure, despite the use of antibiotics. The other possibility is due to the rejection phenomenon, but it was not observed in none of the studied animals.

We did not observe corneal impregnation by pigments. The occurrence of corneal pigmentation ${ }^{(15,21)}$ was not demonstrated in dog's keratoplasties with equine pericardium graft, but was noted when equine amniotic membrane was used for keratectomy repair in same specie ${ }^{(16)}$. It is important to inform that in those studies they had conceived longer periods of evaluation.

\section{CONCLUSION}

In conclusion, the NCM and ACM were integrated into the rabbit cornea with no detectable clinical rejection. Both induced a little corneal vascularization when implanted in cornea by interlamellar graft technique. The ACM induced less corneal vascularization than the NCM. Therefore, these membranes consists in one more graft option for the surgical treatment of corneal repair in rabbits and others animals, when the chances of resolution with other forms of medical and surgical treatment had failed.

\section{ACKNOWLEDGEMENTS}

The authors thank "Fundação de Amparo à Pesquisa do Estado de São Paulo" for the financial support.

\section{RESUMO}

Objetivo: Avaliar os aspectos clínicos e vascularização corneal (VC) induzida pelo enxerto interlamelar das membranas de colágeno nativo (MCN) e de colágeno aniônico (MCA) em córneas de coelhos. Métodos: Um fragmento com $0,25 \mathrm{x}$ $0,25 \mathrm{~cm}$ de MCN (grupo 1) e MCA (grupo 2) foi realizado no olho direito (olho tratado) por enxertia interlamelar. No olho esquerdo (olho controle) foi realizado apenas um túnel estromal. No olho direito (olho controle) foi realizado apenas um túnel estromal. Dezesseis coelhos foram utilizados e foram divididos em dois grupos experimentais composto por oito animais cada. A avaliação clínica foi realizada aos 1, 3, 7, 15 e 30 dias de pós-operatório. A análise da vascularização corneal foi realizada após 30 dias pelo Sistema de analisador de imagens Leica Qwin- $550^{\circledR}$. Resultados: Após 7 dias, a vascularização corneal do limbo em direção central da córnea observada foi de 2,25 $\pm 0,71 \mathrm{~mm}(\mathrm{MCN})$ e $1,0 \pm 1,69 \mathrm{~mm}$ (ACM), respectivamente. Após 15 dias a vascularização corneal aumentou em ambos os grupos $(5,25 \pm 1,03 \mathrm{~mm}-\mathrm{MCN} ; 2,0 \pm$ 2,39 mm - MCA), diminuindo até o $30^{\circ}$ dia $(2,25 \pm 2,10 \mathrm{~mm}$ $\mathrm{MCN} ; 0,75 \pm 2,12 \mathrm{~mm}-\mathrm{MCA})$. A análise estatística indicou que as médias das distâncias dos vasos do limbo em direção ao enxerto observadas após 7 e 15 dias não diferiram estatisticamente $(\mathrm{p}=0,17)$, e 15 e 30 dias de pós-operatório houve tendência a diferir estatisticamente $(\mathrm{p}=0,09)$. Os olhos controles não apresentaram nenhuma alteração. Conclusão: As membranas de colágeno nativo e de colágeno aniônico induzem a vascularização corneal quando aplicadas na córnea de coelhos por meio de enxertia interlamelar, mas membrana de colágeno ativo induz a pequena vascularização corneal quando comparada à membrana de colágeno aniônico. Embora estudos adicionais sejam necessários, os resultados encontrados no presente estudo demonstraram que as membranas de $\mathrm{CN}$ e CA possam ser úteis em ceratoplastias. Estas membranas consistem em mais uma opção de enxerto para o tratamento cirúrgico de reparo da córnea em coelhos e outros animais, quando não há resolução com outras formas de tratamento médico e cirúrgico.

Descritores: Membranas artificiais; Córnea; Colágeno; Ânions; Modelos animais de doenças; Coelhos

\section{REFERENCES}

1. Gilger BC. Diseases and surgery of the canine cornea and sclera. In: Gelatt KN, editor. Veterinary ophthalmology. Oxford: Blackwell; 2007. p.690-752.

2. Andrade AL, Laus JL, Figueiredo F, Batista CM. The use of preserved equine renal capsule to repair lamellar corneal lesions in normal dogs. Vet Ophthalmol 1999;(1):79-82

3. Laus JL, Ferreira AL, Andrade AL. Emprego da escama de sardinha (Sardinella brasiliensis - Steidachner, 1859), preservada em glicerina, no reparo de ceratectomias superficiais em cães (Canis familiaris, LINNAEUS, 1758). Braz J Vet Res Anim Sci [Internet]. 2002[citado 2008 Nov 21];37(2). Disponível em: http:// www.scielo.br/scielo.php?pid=S1413-95962000000100007\&script=sci_arttext

4. Barros PSM, Garcia JA, Laus JL. Preserved equine aminiotic membrane used in the repair of the cornea of the dog. Invest Ophthalmol Vis Sci. 1995;36(4): 982-5.

5. Morales A, Laus JL, Souza MSB, Santos JM, Figueiredo F, Valeri V. Comparação entre enxertos autógenos livres e pediculados de conjuntiva no reparo de ceratectomias superficiais. Estudo experimental no cão (Canis familiaris-LINNAEUS, 1758). Braz J Vet Res Anim Sci. 1996;33(1):28-31.

6. Godoy CAL, Guerra JL, Barros PSM. Ceratoplastia lamelar em cães utilizando membrana fetal equina como enxerto: estudo experimental. Arq Bras Oftalmol. 2002;65(5):545-9.

7. MacSai MS. The management of corneal trauma: advances in the past twentyfive years. Cornea. 2000;19(5):617-24.

8. Costa TAC, Andrade AL, Binotto TE, Plepis AMG, Bevilacqua L, Souza WM de. Avaliações clínica e morfométrica da capacidade angiogênica da membrana de quitosana em córnea de coelhos. Arq Bras Oftalmol. 2006;69(6):817-21. 
9. Lee CH, Singla A, Lee Y. Biomedical applications of collagen. Int J Pharm. 2001;221(1-2):1-22.

10. Lacerda CA, Plepis AMG, Goissis G. Hidrólise seletiva de carboxamidas de resíduos de asparagina e glutamina em colágeno: preparação e caracterização de matrizes aniônicas para uso como biomaterial. Quím Nova. 1998;21(3):267-71.

11. Goissis G, Piccirilli L, Plepis AMG, Das Gupta DK. Preparation and characterization of anionic collagen:P (VDF-TrFE) composites. Pol Eng Sci. 1999; 39(3):474-82.

12. Lee P, Wang CC, Adamis AP. Ocular neovascularization: an epidemiologic review. Surv Ophthalmol. 1998;43(3):245-69.

13. González RP, Leyva A, Melo RAB, Moreira RDM, Pessoa C, Farias RF, et al. Método para estudo in vivo da angiogênese: indução de neovascularização na córnea de coelho. Acta Cir Bras. 2000;15(3):168-73.

14. Gimbrone MA Jr, Cotran RS, Leapman SB, Folkman J. Tumor growth and neovascularization: an experimental model using the rabbit cornea. J Natl Cancer Inst. 1974;52(2):413-27.

15. Barros PSM, Safatle AMV, Malerba TA. Xenologous pericardium as a keratoprosthesis in the dog. An experimental study. In: 24 ${ }^{\text {th }}$ Annual Meeting the
American College of Veterinary Ophthalmologists; Scottsdale; 1993. Proceedings. 1993, p.23.

16. Barros PSM, Garcia JA, Laus JL, Ferreira AL, Gomes TLS. The use of xenologus amniotic membrane to repair canine corneal perforation created by penetrating keratectomy. Vet Ophthalmol. 1998;1(2):119-23.

17. Waring GO. Corneal structure and pathophysiology. In: Leibowitz H, editor. Corneal disorders: clinical diagnosis and management. Philadelphia: WB Saunders; 1984. p.3-25.

18. Girard LJ. Corneal surgery. In: Girard LJ, editor. Advanced techniques in ophthalmic microsurgery. St. Louis: The CV Mosby; 1981. v.2, p.2-26.

19. Naumann GOH, Sautter H. Surgical procedures on the cornea. In: Blodi FC, Mackensen G, Neubauer H, editors. Surgical ophthalmology. Berlin: SpringerVerlag; 1988. v.1, p.434-40.

20. Strieter RM, Kunkel SL, Elner VM, Martonyi CL, Koch AE, Polverini PJ, et al. Interleukin-8. A corneal factor that induces neovascularization. Am J Pathol. 1992;141(6):1279-84.

21. Slatter D. Cornea and sclera. In: Slatter D, editor Fundamentals of veterinary ophthalmology. Philadelphia: WB Saunders; 1990. p.257-303. 